\title{
Land Consolidation Associations and the Management of Territories in Harsh Italian Environments: A Review
}

\author{
Riccardo Beltramo ${ }^{1,2}$, Andrea Rostagno ${ }^{1}$ and Alessandro Bonadonna ${ }^{1,2, *}$ (iD \\ 1 Department of Management, University of Turin, Corso Unione Sovietica 218 bis, 10134 Turin, Italy; \\ riccardo.beltramo@unito.it (R.B.); andrea.rostagno@unito.it (A.R.) \\ 2 NatRisk-Research Centre on Natural Risks in Mountain and Hilly Environments, University of Turin, \\ Largo Paolo Braccini 2, Grugliasco, 10095 Turin, Italy \\ * Correspondence: alessandro.bonadonna@unito.it
}

Received: 18 January 2018; Accepted: 9 March 2018; Published: 13 March 2018

\begin{abstract}
Land fragmentation is a phenomenon that reduces the mechanical management of agricultural and grazing lands and, consequently, leads to the abandonment of agricultural practices in harsh environments. It puts the agricultural and/or agro-pastoral businesses in a difficult situation as they have small surfaces to manage that do not allow for sufficient profit. Some worldwide land consolidation initiatives have been set up to reduce this phenomenon, such as land funds. In this context, this paper is dedicated to an Italian approach, which can be carried over to other realities, aimed at safeguarding and managing territories in harsh environments. This approach, known as the "Associazione Fondiaria (ASFO)", which can be roughly translated as "land consolidation association", consolidates small portions of abandoned land in a functional manner. Indeed, a land consolidation association not only stimulates new entrepreneurial agricultural activities, but is also able to create employment in depressed areas. A SWOT (Strengths, Weaknesses, Opportunities, Threats) analysis was used to evaluate ASFOs, and their peculiarities were discussed.
\end{abstract}

Keywords: land consolidation association; sustainable land management; land fragmentation; abandoned land

\section{Introduction}

The phenomenon of land fragmentation has led to small property decline and is observed especially in harsh environments, due to the division and fragmentation of properties. Frequently, land fragmentation means that agricultural and/or agro-pastoral businesses do not have a large enough surface to manage to allow for sufficient profit $[1,2]$, with obvious negative repercussions on the territory, leading to abandonment and a change in the ecosystem services rendered by meadows, pastures and forests [3]. Territories with problems and criticalities have been identified and labelled as marginalized and disadvantaged, when they represent an economic and social development that does not equal that of the surrounding territorial context [4-7].

This phenomenon has been an object of study the world over and is often seen as an obstacle to productivity and the modernization of agriculture. Although territory fragmentation is often associated with Europe, it has been documented the world over. Some examples can be seen in Taiwan, Malaysia, Japan, the United States, Kenya, Uganda, Peru and Mexico.

The absence of an international standard objective measure, related to the fragmentation of land, not only makes it difficult to compare countries, but also to decide when a farm is too fragmented. 
It has been attested that inheritance is the root cause of the phenomenon of land fragmentation. Indeed, the inheritance laws applied in most countries facilitate, or require, equal division between all heirs. With the passing of generations, this has led to portions of land being increasingly divided up, creating very small pieces of land.

Small farms are the most important types of farms in many developing countries. FAO (Food and Agriculture Organization of the United Nations) reports [8] that Asian and African countries have the smallest average farm size, where $20 / 24$ and 16/20, respectively, cover less than five hectares. Moreover, farms in almost half of the Central American and Oceanian countries are less than five hectares. The situation differs in South American and European countries, where 10/10 and 23/28 countries, respectively, have an average farm size of more than five hectares. In fact, the World Agriculture Census (WCA) of 2000 reported that the companies with the smallest farms in the world are in the Asia-Pacific region. The average size of a farm in Asia is about one hectare, compared to an overall average of 5.5 hectares for 114 member countries of the FAO. In the Pacific Islands, farmland ranges from 0.6 hectares in the Cook Islands to 3.6 in Samoa. Asian farms are traditionally fragmented; in fact, the average agricultural parcels per farm is 3.2 [9]. In some Asian countries, the percentage of small businesses with less than two hectares represents up to $90 \%$ of the total.

Although land fragmentation is often associated with European and Mediterranean countries, the phenomenon has been studied in many others; for example in South Asia, Bangladesh, Vietnam, China, Taiwan, Turkey, USA, Nepal, India, Ethiopia, Ghana and Rwanda, Israel, South Asian countries, Jordan, Peru and Syria [10].

The land fragmentation phenomenon can be reduced by various methods, i.e., land management approaches concerning land consolidation. Land consolidation, an important land management measure, is applied as a solution to land fragmentation and entails a reorganization of the space, with a new land ownership structure in terms of land parcels and landowners, as well as the provision of adequate infrastructures [11-13]. The most important land consolidation approach has been defined as land banking or land funds.

The first international meeting on land banking was organized by FAO and the Ministry of Agriculture of Denmark, at Tonder, in 2004. Jack Damen gave the definition of land banking during this meeting. It was a structural acquisition and temporary management of land in rural areas by a state agency, with the purpose of renting or redistributing land in order to improve the agricultural structure or to reallocate land for other purposes, with a public interest [14]. Indeed, the results of the implementation of land banking in Central and Western Europe have been reported in several studies [14-18]. Another approach is activated by the landowners themselves, when the process of land consolidation is managed by a landowner who is not interested in extending the land, but rather in allowing the land to be used by other farms. This type of cooperative agriculture involves a joint land cultivation by a group of farmers $[19,20]$. This voluntary land exchange amongst landowners is more efficient as the goal is to group the neighboring lots of each landowner.

In this context, the competitiveness of agricultural and agro-industrial systems is one of the objectives set by the European rural development policy [21-24], and it is closely related not only to the improvement of land management, but also to the environment. Indeed, several fields of activity have been identified for the environment, like that of improving the living conditions in rural populations [25,26]; local product sale practices [27-29] and creating an integrated exploitation of human, natural and cultural resources, including landscaping and quality production [30-37].

European policies acknowledge that agriculture follows differentiated development paths, depending on the territory involved. Just how diffuse agriculture is and its economic and social importance can be measured according to various aspects. These include the relationship to the population occupied within the sector, the number of existing production units, the economic value of agricultural production and the role that these productions play in the local economy. In this context, farm concentration, relating to the aggregation and extension of medium-sized businesses [38], is functional for the modernization of production processes and can be considered a consequence of 
modified patterns of agricultural activity management and economic remuneration. The various regional contexts differ and also depend on the specific characteristics of the resources available.

Marginal areas have significant weaknesses, which, if not adequately mitigated by policies, aimed at revitalizing the productive, social and cultural texture, may well represent a threat to the enhancement and safeguarding of these territories [5]. For example, farms are exposed to the effects of many environmental and climatic limitations, which impede the establishment and development of activities.

In this context, land fragmentation contributes to the restriction of the development of the agricultural and forestry sector, as well as the ability of single businesses to reach an adequate economic dimension. In light of the aforementioned information, it can be seen that the Italian land consolidation associations (Associazione Fondiaria-ASFO) make a valuable contribution to the territorial management of disadvantaged areas reducing land fragmentation.

\section{The Phenomenon of Land Fragmentation at an EU Level}

The fragmentation of territorial ownership is a widespread phenomenon at a European level. A useful unit of measure for fragmentation is the Utilized Agricultural Area (UAA). In 2010, the average UAA of European farms was 14.1 hectares, and in countries such as the United Kingdom and Denmark, the value exceeded 60 hectares. On the other hand, Italy is characterized by a widespread fragmentation, with an average UAA value of 7.9 hectares, which is higher than the values recorded in Slovenia (6.5), Croatia (5.6), Greece (4.8), Romania (3.4) and Cyprus (3.0), but lower than those of all the other 28 EU Countries. The relationship between the UAA and the number of enterprises shows territorial differences: apart from the average 152 hectares for farms in the Czech Republic, the states with the largest enterprises include: the United Kingdom, 84 hectares, Slovakia, 78, and Denmark, 63. Amongst the other EU members, Germany has an average UAA of 56 hectares per farm, France 54 and Spain $24[38,39]$ (Table 1).

Table 1. Structure index by country: years 2000-2010. UAA, Utilized Agricultural Area.

\begin{tabular}{|c|c|c|c|c|c|c|}
\hline Countries & Farms, Year 2000 & Farms, Year 2010 & $\begin{array}{l}\text { UAA (ha), } \\
\text { Year } 2000\end{array}$ & $\begin{array}{l}\text { UAA (ha), } \\
\text { Year } 2010\end{array}$ & $\begin{array}{l}\text { Average UAA Per } \\
\text { Farm (ha), Year } 2000\end{array}$ & $\begin{array}{l}\text { Average UAA Per } \\
\text { Farm (ha), Year } 2010\end{array}$ \\
\hline Austria & 199,470 & 150,170 & $3,388,230$ & $2,878,170$ & 16.9 & 19.2 \\
\hline Denmark & 57,830 & 42,100 & $2,644,580$ & $2,646,860$ & 45.7 & 62.9 \\
\hline Finland & 81,190 & 63,870 & $2,218,410$ & $2,290,980$ & 27.3 & 35.9 \\
\hline France & 663,810 & 516,100 & $27,856,310$ & $27,837,290$ & 41.9 & 53.9 \\
\hline Germany & 471,960 & 299,130 & $17,151,560$ & $16,704,040$ & 36.3 & 55.8 \\
\hline Luxembourg & 2810 & 2200 & 127,510 & 131,110 & 45.4 & 59.6 \\
\hline Netherlands & 101,550 & 72,320 & $2,027,800$ & $1,872,350$ & 19.9 & 25.9 \\
\hline Portugal & 415,970 & 305,270 & $3,863,090$ & $3,668,150$ & 9.3 & 12.0 \\
\hline United Kingdom & 233,250 & 186,660 & $15,798,510$ & $15,686,440$ & 67.7 & 84.0 \\
\hline Spain & $1,287,420$ & 989,800 & $26,158,410$ & $23,752,690$ & 20.3 & 24.0 \\
\hline Sweden & 81,410 & 71,090 & $3,073,200$ & $3,066,320$ & 37.7 & 43.1 \\
\hline Estonia & & 19,610 & & 940,930 & & 48.0 \\
\hline Latvia & & 83,390 & & $1,796,290$ & & 21.5 \\
\hline Lithuania & & 199,910 & & $2,742,560$ & & 13.7 \\
\hline Malta & & 12,530 & & 11,450 & & 0.9 \\
\hline Poland & & $1,506,620$ & & $14,447,290$ & & 9.6 \\
\hline Czech Republic & & 22,860 & & $3,483,500$ & & 152.4 \\
\hline Romania & & $3,859,040$ & & $13,306,130$ & & 3.4 \\
\hline Slovakia & & 24,460 & & $1,895,500$ & & 77.5 \\
\hline Slovenia & & 74,650 & & 482,650 & & 6.5 \\
\hline Hungary & & 576,810 & & $4,686,340$ & & 8.1 \\
\hline New members & & $7,022,510$ & & $49,702,580$ & & 7.1 \\
\hline EU 28 & & $12,247,850$ & & $172,920,330$ & & 14.1 \\
\hline
\end{tabular}

Source: Authors' elaboration on [38-40]. 
The size of an enterprise depends both on the shape of the land itself and its use. The largest farms are those for the cultivation of arable crops in the major plains of Central Europe; whilst permanent cultivation, typical of Mediterranean countries, covers smaller surfaces as more substantial investments are required [41]. However, in Italy, the average size of farmland increased in the period 2000-2010, shifting from 5.5 hectares of UAA per company to $7.9(+44.4 \%)$. This is due to a sharp reduction in the number of active farms and livestock companies $(-32.2 \%)$, which is reflected in a drop in the less cultivated areas $(-2.3 \%)[38,40]$.

The impact of community policies and market trends has led to numerous small businesses leaving the sector, favoring the concentration of agricultural and zoo-technical activities into larger units, thus reducing the gap between Italy and the European average [38]. The average corporate size in terms of TAS (Total Agricultural Surface) is also higher than it was in 2000. In fact, there was an increase from $7.8-10.6$ hectares [38,41].

As there are numerous Less Favored Areas (LFAs) in the European Union (EU), interest in this phenomenon is very high $[42,43]$. Currently, there has been a rise in the abandonment of agricultural areas in the EU (-2.82\% of UAA, in the period 2000-2010), due to depopulation and a decline in traditional activities, leading to a reduction in economic, social and cultural systems in LFAs.

Indeed, numerous authors have reported that marginal areas have permanent natural handicaps due to topographic and climatic restrictions on the economic activities $[4,7,42,43]$. Therefore, land fragmentation is a current phenomenon, and territorial consolidation offers a solution to the safeguarding of territories.

Basically, there are three ways to obtain land consolidation, i.e., voluntary, mandatory or a hybrid of the two. Voluntary land consolidation has been carried out in countries like the Czech Republic, Denmark, France, Switzerland and the Netherlands. However, the process has, at times, been slow and has led to unsatisfactory results [44-46].

Mandatory land consolidation, i.e., that imposed by governments, has led to issues such as poor cooperation and landowner resistance. One such example is that of Slovenia, where the owners contested the government's decision to proceed with mandatory land consolidation. Another example is connected to the German land consolidation law that stipulates that the Land Consolidation Authority may start a project only if there is a long tradition of success, making for a slow process [45]. The hybrid solution, as the name implies, is a combination of the two aforementioned systems. Therefore, a voluntary partial consolidation means that when some landowners agree with the implementation of the project, then others might follow. Furthermore, the landowners in favor of land consolidation usually hold a substantial amount of land, in terms of area or economic value $[45,47]$.

One of the main aims of the EU policies has been that of reducing disparities between urban and rural areas, by improving the rural conditions of its member states. Indeed, the EU has included land consolidation as a measure within its overall rural development policy. Some countries have made decisions on how to manage the issue. Indeed, Greece, the Netherlands, Portugal and Sweden have adopted a majority agreement. This states that before a project can be started, more than $50 \%$ of the land owners, in terms of size/value of the territory, must be interested in taking part. Many countries have legislations that allow for mandatory land consolidation to be applied in special cases, usually when it is part of an integrated rural program. However, the success of land consolidation is strongly dependent on landowners' acceptance, as it involves the management of their property directly [48-50]. In this context, an approach, which may be carried over to other countries, has been implemented to reach the goal of land consolidation in both France and in Italy.

\section{The Land Consolidation Association Approach}

The first initiatives designed to contain the phenomenon of land fragmentation and the abandonment of land in rural areas were implemented in France through the establishment of the Association foncière pastorale and the Groupements pastoraux [51]. These approaches are aimed at a productive recovery of abandoned surfaces and the establishment of territorial bases for organized 
pastoral use, in agreement with producers' associations and local consortiums. The French legislation is functional, and initiatives are supported and encouraged by the state and local communities [52,53].

The first Italian project was implemented by the Piedmont Region, which regulated land consolidation associations by the Regional Law on "Provisions to promote the establishment of Land Consolidation Associations and the development of agricultural and forestry lands". The Piedmont Region has undertaken to repay the costs incurred for the setup of land consolidation associations, up to a maximum of $80 \%$. A further incentive comes from granting those private landowners who join a land consolidation association the sum of 500 Euro per hectare assigned, provided that the commitment lasts for no less than 15 years; an initiative that can be adopted elsewhere.

The Piedmont Region recognizes and promotes land consolidation associations to incentivize the enhancement of landowners' properties. A land consolidation association operates mainly on four lines of action:

- the associated management of the plots conferred or assigned by participants;

- the writing and implementation of a management plan for the plots conferred or assigned by participants, where the best technical and economic solutions are identified according to the objectives of agricultural and forestry production, as well as environment and landscape conservation;

- participation, in agreement with the municipality/municipalities, in the identification of silent land and its productive reclamation, according to the Italian law 440/1978;

- ordinary and extraordinary maintenance of land and landscaping works (Regional Law 2 November 2016, No. 21).

Currently, there are 13 Italian ASFOs, which have either been established or are in the process of being so. The first two were established in 2012 as a private initiative in Piedmont, in the municipalities of Briga Alta (Cuneo) and Carnino (Cuneo) and in the municipality of Avolasca (Alessandria). The proposal convinced the owners of abandoned land to associate with the aim of promoting the use and conservation of the productive potential and landscape value in those areas.

However, before 2012 in Piedmont, as in other Italian regions, there was no regional law regulating ASFOs. This legislative omission has incentivized the establishment of voluntary land consolidation associations amongst the owners of abandoned land in one or more municipalities.

Currently, 10/13 ASFOs are in Piedmont, 4 in the province of Cuneo, 3 in the province of Alessandria and 3 in the province of Turin. Whilst, in other Italian regions, there is 1 in the Aosta Valley, 1 in Friuli-Venezia Giulia and 1 in Lombardy.

Founding members establish an ASFO by signing the charter and drafting and signing membership minutes. This documentation can be regularly registered at the Registry Office without any notary fees. Public authorities, such as individual or associated municipalities in the Union, play a key role in promoting initiatives aimed at disseminating associative culture among landowners. They can provide information and technical support to associations and assign fallow and abandoned plots on the basis of a plan. The mayors of the municipalities assign abandoned, fallow land and silent land, i.e., the owner is unknown, to land consolidation associations [54].

\section{Methodology}

This paper evaluates how a land consolidation association is able to improve the territorial management of LFAs. On the one hand, the rationalization of homogeneous areas maximizes the potential of a marginal area and solves the problem of land fragmentation. On the other, new forms of territorial management can be analyzed to permit a convenient combination of abandoned surfaces. In this context, the purpose of land consolidation is to activate production recovery processes in these areas, ensuring sufficient profitability for agro-pastoral companies [2] and safeguarding ecosystem services rendered by meadows and pastures [3].

One of the most useful tools to predict the effectiveness of the decisions to be made in the field of strategic planning is SWOT analysis. Therefore, it was chosen as a tool to evaluate the phenomenon to 
pursue the objective of this study. The SWOT matrix is organized into four sections and evidences the salient points of the ASFO area-related analysis. This technique combines the evaluation of the internal and external favorable and unfavorable factors of the organization under study. Indeed, the term SWOT is the acronym for Strengths (internal favorable factors), i.e., the peculiarities of the association that give it an advantage over others, Weaknesses (internal unfavorable factors), i.e., the characteristics that place the association at a disadvantage compared to others, Opportunities (external favorable factors), i.e., the features of the external environment that the association could exploit to its advantage, and Threats (external unfavorable factors), i.e., the features of the external environment that could cause problems for the association $[55,56]$. SWOT analysis is a supportive choice analysis that responds to a need to rationalize decision making processes. This technique was developed to support business strategies in contexts characterized by uncertainty and strong competitiveness. It is a cognitive tool that allows for the definition of an intervention program in a sectorial or territorial context, based on the identification of the potentialities and criticalities of the system under analysis [55].

The use of this method has been extended to territorial diagnosis and the evaluation of regional programs [57]. This analysis may refer to the territory covered by the intervention, to the sector concerned, individual sectors and to the priority issues where a program is developed [56], maximizing the potential of creating value [58]. One such example of its application was its support of the Sicilian agro-food production and its application to strengthen the producers' role in the supply chains [59]. The aim of this study was to verify the potential of the theoretical model based on a SWOT analysis. Moreover, it has been demonstrated to be an effective tool for the analysis of the internal and external competitiveness of a system [60].

Indeed, taken as a whole, the SWOT analysis methodology is useful to support the decision making and operational activities of public and private actors involved in strategic goals [61] and can facilitate the evaluation of phenomena affecting the territory [62,63]. Decision making processes related to interventions on the territory are characterized by an integration of many tools, such as SWOT analysis, with the aim of creating synergies and feasibility for the definition of complex territorial policies $[64,65]$. In this context, this model of analysis is a process providing systemically accessible information on a specific theme, such as ASFOs. Therefore, this analysis applies a matrix to the ASFOs that have already been established, as well as those still to be established.

\section{Results}

This work is based on the ASFO review of a bibliographic collection, searching for those that emphasize interrelations between managing and the safeguarding of territories in harsh environments. A SWOT matrix was developed where the most relevant aspects were highlighted and classified as strengths, weaknesses, opportunities or threats (Table 2).

Table 2. The Associazione Fondiaria (ASFO) SWOT analysis matrix for managing and safeguarding territories in harsh environments.

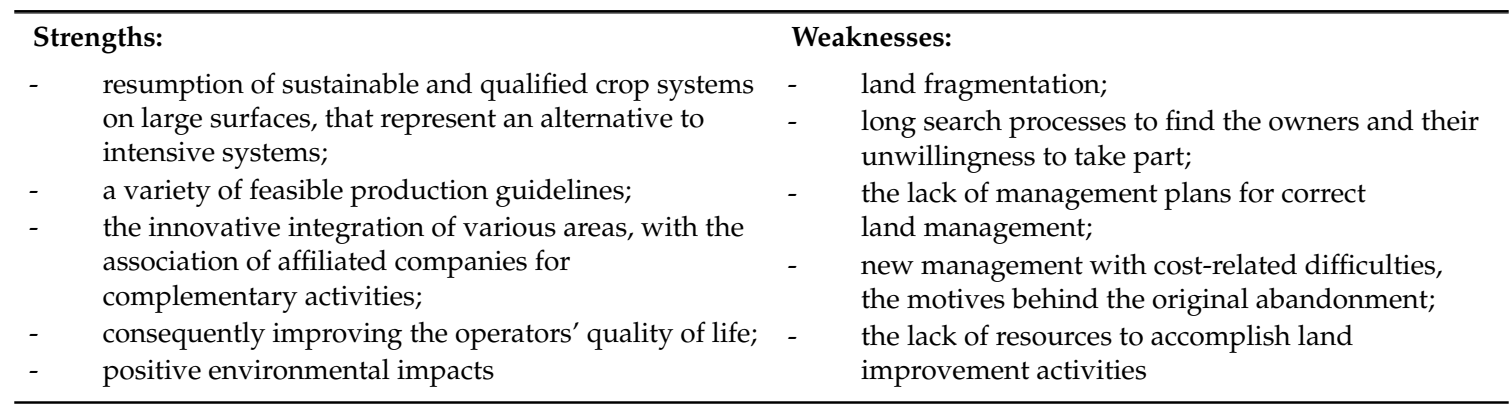


Table 2. Cont.

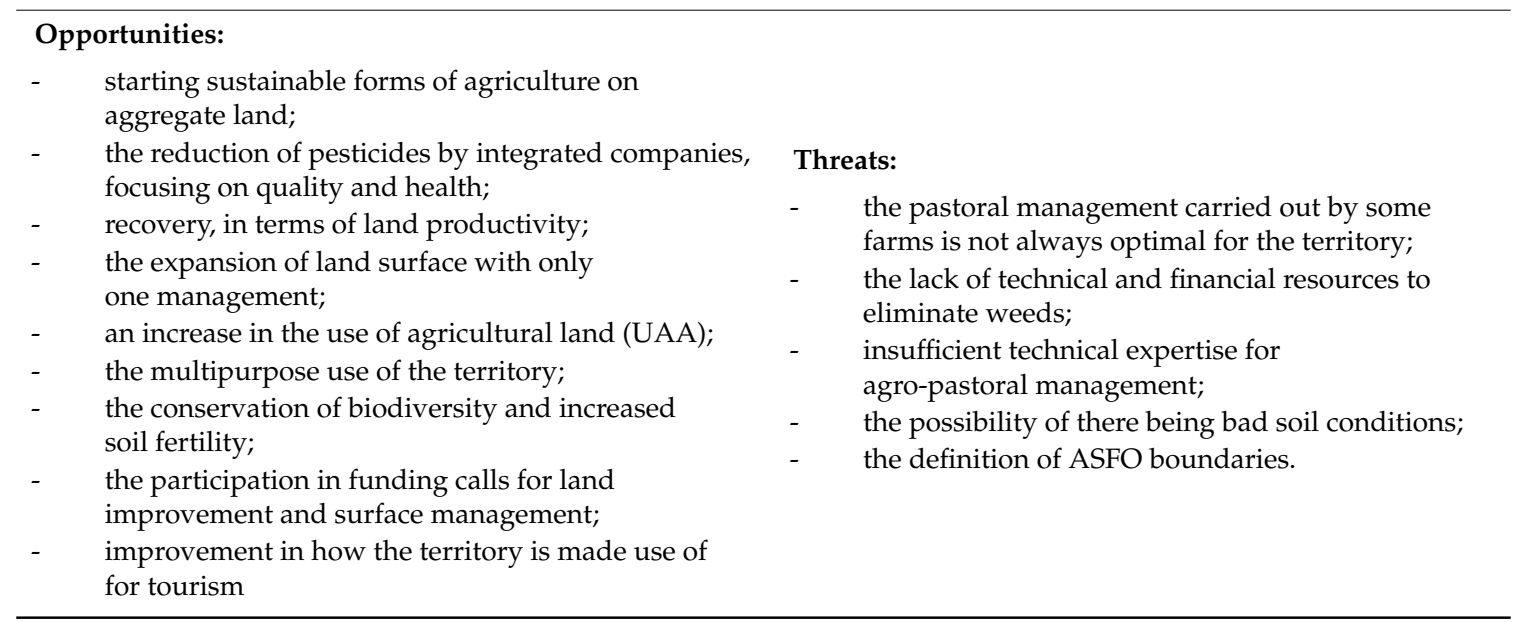

Some important aspects of ASFOs emerged from the SWOT analysis: most of them can be traced back to land fragmentation, environmental sustainability and stakeholder management opportunities.

\subsection{Land Fragmentation}

Marginal land cannot ensure the preservation of agricultural activities in hilly and mountainous areas, if the problem of greater short-term profitability for the farms involved is not solved. This could be achieved through a functional expansion of their size and product valorization. The western and central Alps and the hilly areas of Italy are more penalized than the eastern Alps, where valleys tend to be easier to cultivate and public administrations are more open to resource-conscious management, favoring the conservation of many functional companies [66].

A landscaping and historical cultural heritage, the result of a multi-century woodland-agropastoral cycle, seems to have survived in numerous alpine valleys and hilly areas [67]. However, an in-depth analysis highlighted that a precarious situation is connected to the initiatives taken by individual farmers, as they are rarely linked to an overall project that was requested and supported by the community as a whole to introduce a different use of the mountains and/or hills [68,69]. Land recovery instruments, such as buying, exchanging or renting plots, cannot be used for fallow, abandoned and/or fragmented land.

Farms operating in the territory belong to the private and public sectors. The first is characterized by family businesses working closely with local resources. Their success is linked to resource enhancement and the adaptive ability to take advantage of multifunctional features. Agricultural products build chains with many valorization activities and maintain strong identity ties with the area of origin. There has also been a widespread depopulation of the mountainous and high hilly areas since the Second World War, which was followed by rapid changes in agricultural working conditions. The decline in farms has not been offset by a corresponding increase in the average size of farms in almost all Italian mountain and high hill areas.

If the phenomenon of land fragmentation is to be contrasted, the integration of public actions is a must. These are to be carried out at a local and regional level and should, at the same time, enhance businesses, their productions and the economic and social activities in their territories, with support actions based on the promotion of natural resources, ensuring their correct exploitation and sustainable use. The Italian ASFO instrument is placed in this context.

\subsection{Environmental Sustainability}

Land consolidation associations have different functions and properties, which can be summarized in the conservation of plant and animal biodiversity [70,71] and of pastures and alpine vegetal 
biodiversity through different vegetation formations [67]. Only if there is a mosaic of different habitats with a large proportion of herbaceous formations can a territorial high biodiversity be maintained. Moreover, agro-pastoral management contributes to an increase in biodiversity and "cultural" landscapes. In this context, ASFOs enhance attractiveness for tourism and recreation. The wide variety of vegetation formations make for more enjoyable landscapes that may be used in numerous summer and winter touristic activities. Correct and attentive management, like grazing, can reduce the risk of fire, as turning the grass over eliminates the accumulation of flammable dry phytonutrients almost completely.

Another interesting aspect is the increase in soil fertility and a reduced danger of hydrogeological instability. Through the fertilization process, regular use of agro-pastoral surfaces contributes to the enrichment of organic matter content present in the soil, with beneficial effects on the pedosphere. Here, again, ASFOs have an excellent level of sustainability and are capable of improving landscape and environmental conditions in both the public and private interest. Moreover, the environmental sustainability of ASFOs can also be evaluated on the basis of the potential and productivity of pasture surfaces that can support pastoral business realities.

\subsection{Stakeholders and Opportunity Management}

In order to ensure that commitment to an ASFO can lead to a long-term recovery of the territory, its objectives must be defined. Therefore, the identification of crops suitable for soil typology, quota and exposure is the first step towards enhancing the final product. The same goes for the forest plan, i.e., the planning of a wood supply chain that takes into account the areas of intervention, the lots and the type of timber.

This is a clear point in the Italian regional legislature that foresees among the priority activities of an ASFO that of the drafting and implementation of a land management plan that identifies "the best technical and economic solutions, depending on the objectives of agricultural and forestry production and the conservation of the land, environment and landscape" (Regional Law 2 November 2016, No. 21). Working within an ASFO will strongly incentivize farmers, who can benefit from an effective management plan for better resource utilization and improved product offers. In fact, the plan will lay the basis for the compilation of the cadaster, which is the cognitive approach to the pastoral resource, with a description of the individual production units. It makes a quantitative evaluation of the dairy and zoo-technical production that can be obtained by each fodder unit, as a prerequisite for certification of their origin and appropriate valorization $[72,73]$.

\section{Discussion and Conclusions}

Land consolidation aims at supporting rural development towards the reorganization of land, where the fundamental action of the consolidation process is the rehabilitation of the territory, implemented on a voluntary or compulsory basis, i.e., it depends on local policies. Some land consolidation projects have been successful. Indeed, the phenomenon of land banking is a mandatory factor for the reallocation of multipurpose land [14]. Moreover, land funds contribute to overcoming a key constraint on the ownership of agricultural land [15]. This paper shows that the land consolidation association focuses its attention on the creation of active companies and can take an active part in the land consolidation process and development of the territories, in line with other territories like Western Europe [15]. It is a useful approach to the concentration of land and takes into consideration the conditions of land ownership and land registry problems, as well as contributing to overcoming a key constraint as to the ownership of agricultural land, as reported by Van Dijk [11,12] and Van Dijk and Kopeva [15]. Moreover, it represents a feasible approach to implement the expansion and consolidation of farms and satisfies the reallocation of multipurpose land [14]. However, a land policy applied to one country may not be likewise applicable to another, as reported by Van Dijk [11]. In this context, through the analysis of ASFOs as an approach for territorial management of disadvantaged areas, this paper evidences how a participatory process involving the stakeholders present in the 
territory, i.e., municipal administrations, consortiums, landowners, citizens, agro-pastoral companies and agronomists/forest experts/experts in agro-pastoral management, is an indispensable point if the final goals are to be achieved.

The ASFO distinguishes itself in its aim to identify technical advice in the area of agro-pastoral management. It provides guidelines on how to solve existing business criticalities and improve the landscape, the environment and the profitability of companies, also through the promotion of touristic activities. Moreover, it can endorse associated management of agro-pastoral areas to coordinate and manage existing experiences and expand them to plots still lacking associated management.

Moreover, it must not be forgotten that an ASFO is a common association between individuals, which can be formed under the guidance of a municipality and/or a union of municipalities. Public authorities, especially municipalities and their aggregations, are an important ally in ASFO activities. They act as promoters of the initiative and support it on technical aspects, like the identification of cadastral particles and their owners, the presence of water and access roads to the plots. Their contribution becomes indispensable when it comes to uncultivated and/or silent land where there is no known owner. Therefore, the responsibility of locating land exposed to hydrogeological and fire risk and that of conferring it to the local ASFO lies with the municipalities. The public authority, exercising this substitute power, as a remedy to owners' inertia, takes on both the function of a guarantor and monitors the maintenance and good use of the land. It also commits itself to the restitution of the allotted land to the legitimate owners should they legitimately claim the property back. In this context, municipal administrations could supervise and stimulate this process by encouraging new landowners to join and adopt solutions that ensure greater solidity and functionality for the realities created.

\section{Limitations, Implications and Future Research}

As the ASFO phenomenon is a relatively recent one, the time span our analysis has been able to cover is limited, meaning that further research is to be carried out before a detailed evaluation of whether or not the expected benefits have been effectively achieved. In Piedmont, the 2016 Regional Law is facilitating the creation of new ASFOs, through the incentives made available, leading to the revival of agro-pastoral companies. It would be desirable to implement a pathway towards National and European legislation, disseminating ASFO competences to all rural areas in the EU.

A future analysis of the ASFO phenomenon is ongoing to assess the efficacy of this type of approach by a survey dedicated to active ASFOs. Furthermore, an in-depth analysis of the ASFO management, technical and relational features will be carried out with the aim of reducing land fragmentation and safeguarding/reproducing biodiversity and local resources.

Acknowledgments: The authors thank Barbara Wade of the University of Turin, for her linguistic review.

Author Contributions: The authors contributed fully and equally in this study.

Conflicts of Interest: The authors declare no conflict of interest.

\section{References}

1. Colombo, S.; Perujo Villanueva, M. The inefficiency and production costs due to parcel fragmentation in olive orchards. New Medit 2017, 16, 2-10.

2. UNCEM. Associazioni Fondiarie, L'alternativa Possibile All'abbandono del Territorio. Piemonti-Periodico D'informazione della Delegazione Piemontese UNCEM, Marzo 2017, n. 1. Available online: http:/ /www.regione.piemonte.it/pinforma/economia/739-le-associazioni-fondiarie-contro-labbandono-delle-terre-montane.html (accessed on 22 November 2017). (In Italian)

3. Probo, M.; Cavallero, A.; Lonati, M. Gestione Associata delle Superfici Agro-Pastorali del Comune di Pragelato (To); Edizioni DISAFA, Università degli Studi di Torino: Grugliasco, Italy, 2016; p. 47, ISBN 978-88-99108-07-6. (In Italian) 
4. MacDonald, D.; Crabtree, J.R.; Wiesinger, G.; Dax, T.; Stamou, N.; Fleury, P.; Lazpita, J.G.; Gibon, A. Agricultural abandonment in mountain areas of Europe: Environmental consequences and policy response. J. Environ. Manag. 2000, 59, 47-69. [CrossRef]

5. Rey Benayas, J.M.; Martins, A.; Nicolau, J.M.; Schulz, J.J. Abandonment of agricultural land: An overview of drivers and consequences. CAB Rev. 2007, 2, 1-14. [CrossRef]

6. Renwick, A.; Jansson, T.; Verburg, P.H.; Revoredo-Giha, C.; Britz, W.; Gocht, A.; McCracken, D. Policy reform and agricultural land abandonment in the EU. Land Use Policy 2013, 30, 446-457. [CrossRef]

7. Hinojosa, L.; Napoléone, C.; Moulery, M.; Lambin, E.F. The "mountain effect" in the abandonment of grasslands: Insights from the French Southern Alps. Agric. Ecosyst. Environ. 2016, 221, 115-124. [CrossRef]

8. Food and Agriculture Organization of the United Nations (FAO). 2000 World Census of Agriculture, Analysis and International Comparison of the Results (1996-2005); Food and Agriculture Organization of the United Nations: Rome, Italy, 2000.

9. Food and Agriculture Organization of the United Nations (FAO). Asia and Pacific commission on Agricultural Statistics-Twenty-Third Session; Food and Agriculture Organization of the United Nations: Rome, Italy, 2010.

10. Demetriou, D. The Development of an Integrated Planning and Decision Support System (IPDSS) for Land Consolidation; Springer: Cham, Switzerland, 2014; p. 340, ISBN 978-3-319-02346-5.

11. Van Dijk, T. Dealing with Central European Land Fragmentation: A Critical Assessment on the Use of Western Instruments; Eburon: Delft, The Netherlands, 2003; p. 219, ISBN 90-5166-996-8.

12. Van Dijk, T. Complications for traditional land consolidation in Central Europe. Geoforum 2007, 38, 505-511. [CrossRef]

13. Hartvigsen, M. Land Consolidation in Central and Eastern European Countries. In Proceedings of the Shaping the Change, the XXIII FIG Congress, Munich, Germany, 8-13 October 2006.

14. Damen, J. Land banking in The Netherlands in the context of land consolidation. In Proceedings of the Land Banking/Land Funds as an Instrument for Improved Land Management for CEEC and CIS, Tonder, Denmark, 17-20 March 2004.

15. Van Dijk, T.; Kopeva, D. Land banking and Central Europe: Future relevance, current initiatives, Western European past experience. Land Use Policy 2006, 23, 286-301. [CrossRef]

16. Milićević, D. Review of existing land funds in European countries. Geonauka 2014, 2, 31-42. [CrossRef]

17. Food and Agriculture Organization of the United Nations (FAO). Experiences with Land Consolidation and Land Banking in Central and Eastern Europe after 1989; Working Paper NO. 26; Food and Agriculture Organization of the United Nations: Rome, Italy, 2015.

18. Marošan, S.; Milićević, D.; Đokić, V.; Šoškić, M. Value framework for evaluation of land banks/funds. Geodetski Vestnik 2014, 58, 568-577. [CrossRef]

19. Engindeniz, S.; Yercan, M. An approach for turkish agriculture: Group farming. Die Bodenkultur 2002, 53, 227-233.

20. Milovanovic, V.; Smutka, L.; Jusufi, G. Cooperative farming potential for establishing food security within rural bangladesh. Acta Univ. Agric. Silvicult. Mendel. Brun. 2016, 64, 2067-2074. [CrossRef]

21. Westhoek, H.J.; Van den Berg, M.; Bakkes, J.A. Scenario development to explore the future of Europe's rural areas. Agric. Ecosyst. Environ. 2006, 114, 7-20. [CrossRef]

22. Vandenberghe, C.; Freléchoux, F.; Moravie, M.; Gadallah, F.; Buttler, A. Short-term effects of cattle browsing on tree sapling growth in mountain wooded pastures. Plant Ecol. 2007, 188, 253-264. [CrossRef]

23. Galdeano-Gómez, E.; Aznar-Sánchez, J.A.; Pérez-Mesa, J.C. The complexity of theories on rural development in Europe: An analysis of the paradigmatic case of Almería (South-east Spain). Sociol. Rural. 2011, 51. [CrossRef]

24. Zasada, I.; Häfner, K.; Schaller, L.; Van Zanten, B.T.; Lefebvre, M.; Malak-Rawlikowska, A.; Nikolov, D.; Rodríguez-Entrena, M.; Manrique, R.; Ungaro, F.; et al. A conceptual model to integrate the regional context in landscape policy, management and contribution to rural development: Literature review and European case study evidence. Geoforum 2017, 82, 1-12. [CrossRef]

25. D'Agostini, L.R.; Fantini, A.C. Quality of life and quality of living conditions in rural areas: Distinctively perceived and quantitatively distinguished. Soc. Indic. Res. 2008, 89, 487-499. [CrossRef]

26. Chambers, R. Rural Development, Putting the Last First; Routledge-Taylor \& Francis Group: London, UK; New York, NY, USA, 2013; pp. 1-235, ISBN 0-582-64443-7. 
27. Bonadonna, A.; Duglio, S. A Mountain Niche Production: The case of Bettelmatt cheese in the Antigorio and Formazza Valleys (Piedmont-Italy). Qual. Access Success 2016, 17, 80-86.

28. Baritaux, V.; Tebby, C.; Revoredo-Giha, C. How well do food retailers know their customers? The case of mountain food products in Europe. J. Chain Netw. Sci. 2011, 11, 223-234. [CrossRef]

29. Brun, F.; Mosso, A. The development of a Piedmont mountain area through the valorisation of black truffle. Riv. Econ. Agric. 2016, 71, 435-442. [CrossRef]

30. Bonadonna, A.; Peira, G.; Varese, E. The European optional quality term "Mountain Product": Hypothetical application in the production chain of a traditional dairy product. Qual. Access Success 2015, 16, 99-104.

31. Bonadonna, A. What does the Optional Quality Term "Mountain Product" involve? The Biellese Mountain (North-west Italy) farmers' opinion. Mediterr. J. Soc. Sci. 2016, 7, 18-23. [CrossRef]

32. Finco, A.; Bentivoglio, D.; Bucci, G. A label for mountain products? Let's turn it over to producers and retailers. Qual. Access Success 2017, 18, 198-205.

33. Bonadonna, A.; Peira, G.; Giachino, C.; Molinaro, L. Traditional cheese production and an EU labeling scheme: The Alpine cheese producers' opinion. Agric. Lond. 2017, 7, 65. [CrossRef]

34. Fleury, P.; Petit, S.; Dobremez, L.; Schermer, M.; Kirchengast, C.; De Ros, G.; Magnani, N.; Struffi, L.; Mieville-Ott, V.; Roque, O. Implementing sustainable agriculture and rural development in the European Alps: Assets and limitations of local projects based on multi-stakeholder participation. Mt. Res. Dev. 2008, 28, 226-232. [CrossRef]

35. Giampietri, E.; Finco, A.; Del Giudice, T. Exploring consumers' attitude towards purchasing in short food supply chain. Qual. Access Success 2015, 16, 135.

36. Rey, R. New challenges and opportunities for mountain agri-food economy in South Eastern Europe. A scenario for efficient and sustainable use of mountain product, based on the family farm, in an innovative, adapted cooperative associative system-horizon 2040. Proc. Econ. Financ. 2015, 22, 723-732. [CrossRef]

37. Sidali, K.L.; Kastenholz, E.; Bianchi, R. Food tourism, niche markets and products in rural tourism: Combining the intimacy model and the experience economy as a rural development strategy. J. Sustain. Tour. 2015, 23, 1179-1197. [CrossRef]

38. ISTAT. $6^{\circ}$ Censimento Generale dell'Agricoltura, Risultati, ISTAT. 2011. Available online: https: / / www.istat. it/it/archivio/ 66591 (accessed on 16 January 2018). (In Italian)

39. EUROSTAT. Available online: http:/ / ec.europa.eu/eurostat/data/database (accessed on 9 February 2018).

40. ISTAT. ISTAT Lo Spazio Economico Dell'agricoltura Veneta; ISTAT: Regione Veneto, Italy, 2006; pp. 185-214. (In Italian)

41. ISMEA Agriturismo e Multifunzionalità dell'Azienda Agricola—Strumenti e Tecniche per il Management, Mipaaf Autorità di Gestione. 2016. Available online: http:/ / www.reterurale.it/downloads/Agriturismo_ multifunzionalit\%C3\%A0.pdf (accessed on 16 October 2017). (In Italian)

42. Schuler, M.; Stucki, E.; Roque, O.; Perlik, M. Mountain Areas in Europe: Analysis of Mountain Areas in EU Member States, Acceding and Other European Countries; Final Report; European Commission: Brussels, Belgium, 2004. Available online: http:/ / ec.europa.eu/regional_policy/sources/docgener/studies/pdf/montagne/ mount1.pdf (accessed on 9 February 2018).

43. Rural Development in the EU, Statistical and Economic Information. Report 2013. Available online: https: / / ec.europa.eu/agriculture/statistics/rural-development_it (accessed on 10 February 2018).

44. Kovandova, M. Could the Land Consolidation Process Be an Effective Tool for Nature and Environmental Protection in the Czech Republic? In Proceedings of the Shaping the Change, the XXIII FIG Congress, Munich, Germany, 8-13 October 2006.

45. Zhou, J.M. How to Carry Out Land Consolidation an International Comparison; European University Institute, Department of Economics: Fiesole, Italy, 1999. Available online: http:/ / cadmus.eui.eu/bitstream/handle/ 1814/686/ECO99-1.pdf?sequence=1 (accessed on 9 February 2018).

46. Niroula, G.S.; Thapa, G.B. Impacts and causes of land fragmentation, and lesson learned from land consolidation in South Asia. Land Use Policy 2005, 22, 358-372. [CrossRef]

47. Bullard, R. Land Consolidation and Rural Development; Papers in Land Management; Anglia Ruskin University: Cambridge, UK, 2007.

48. Food and Agriculture Organization of the United Nations (FAO). The Design of Land Consolidation Pilot Projects in Central and Eastern Europe; Food and Agriculture Organization of the United Nations: Rome, Italy, 2003; ISBN 978-92-5-105974-6. 
49. Thomas, J. What's on regarding land consolidation in Europe? In Proceedings of the Shaping the Change, the XXIII FIG Congress, Munich, Germany, 8-13 October 2006.

50. Food and Agriculture Organization of the United Nations (FAO). Opportunities to Mainstream Land Consolidation in Rural Development Programmes of the European Union; Food and Agriculture Organization of the United Nations: Rome, Italy, 2008; ISBN 978-92-5-105974-6.

51. Charbonnier, Q.; Romagny, T. Pastoralismes d'Europe, Rendez-vous avec la modernité! Cardère Editeur: Avignon, France, 2012; p. 176, ISBN 978-2-914053-64-8. (In French)

52. Quentin, C. 1972, La loi Pastorale Française; Cardère Editeur: Avignon, France, 2012; p. 141, ISBN 9782914053655. (In French)

53. Eychenne, C. Quelles incursions du territoire dans l'évolution d'une politique sectorielle? Discours et representation sautour de l'agriculture de montagne. Sud-Ouest Eur. 2012, 34, 9-20. [CrossRef]

54. CREA. Come Favorire la Domanda Innovativa di Accesso Alla Terra Nelle Aree Interne. Proposte per tre Linee di Azione, Seminario Promosso dal CREA: Accesso Alla Terra, Pratiche sul Territorio e Politiche Pubbliche 7-8 Luglio 2016-Finale di Pollina (PA). Available online: http://www.agenziacoesione.gov.it/opencms/export/sites/dps/it/documentazione/Aree_interne/ Eventi/Seminario_Pollina_luglio_2016/documento_Madonie_accesso_alla_terra_rev_x28_dicx.pdf (accessed on 15 January 2018) (In Italian).

55. Storti, D. L'analisi SWOT; Università degli Studi di Reggio Calabria: Reggio Calabria, Italy, 2014. Available online: https://www.unirc.it/documentazione/materiale_didattico/598_2009_170_5598.pdf (accessed on 17 December 2017). (In Italian)

56. Valentin, E.K. SWOT analysis from a resource-based view. J. Mark. Theory Pract. 2001, 9, 54-69. [CrossRef]

57. Karppi, I.; Kokkonen, M.; Lähteenmäki-Smith, K. SWOT-Analysis as a Basis for Regional Strategies; Nordregio Working Paper; Nordic Centre for Spatial Development: Stockholm, Sweden, 2001; pp. 1-84, ISSN 1403-2511.

58. Coman, A.; Boaz Ronen, B. Focused SWOT: Diagnosing critical strengths and weaknesses. Int. J. Prod. Res. 2009, 47, 5677-5689. [CrossRef]

59. Rapisarda, P.; Rizzo, M.; Scuderi, A. Analysis of a direct selling network for agrifood products. Ital. J. Food Sci. 2015, 27, 109-117. [CrossRef]

60. Niu, D.; Song, Z.; Xiao, X. Electric power substitution for coal in China: Status quo and SWOT analysis. Renew. Sustain. Energy Rev. 2017, 70, 610-622. [CrossRef]

61. Frisio, D. I punti di forza e di debolezza, le minacce e le opportunità. In Riforma della Pac e Impatto sul Sistema Agricolo Lombardo; Regione Lombardia: Milano, Italy, 2004; pp. 213-224. (In Italian)

62. Mipaaf. Analisi SWOT e Identificazione dei Fabbisogni dei PSR 2014-2020, Mipaaf, Luglio 2013. Available online: http:/ / www.reterurale.it/flex/cm/pages/ServeBLOB.php/L/IT/IDPagina/12029 (accessed on 17 January 2018). (In Italian)

63. Comino, E.; Ferretti, V. Indicators-based spatial SWOT analysis: Supporting the strategic planning and management of complex territorial systems. Ecol. Indic. 2016, 60, 1104-1117. [CrossRef]

64. Ferretti, V. From stakeholder analysis to cognitive mapping and Multi-Attribute Value Theory: An integrated approach for policy support. Eur. J. Oper. Res. 2016, 253, 524-541. [CrossRef]

65. Ferretti, V.; Montibeller, G. Key challenges and meta-choices in spatial multicriteria evaluation for environmental decision-making. Decis. Support Syst. 2016, 84, 41-52. [CrossRef]

66. ArchAlp. Paesaggi della Terra, Agricoltura e Architettura, Centro di Ricerca Istituto di Architettura Montana, Giugno 2016. Available online: https:/ / areeweb.polito.it/ricerca/IAM/wp-content/uploads/2016/07/ ArchAlp_11-1.pdf (accessed on 21 September 2017). (In Italian)

67. Cavallero, A.; Aceto, P.; Gorlier, A.; Lombardi, G.; Lonati, M.; Martinasso, B.; Tagliatori, C. I tipi Pastorali delle Alpi Piemontesi; Alberto PerdisaEditore: Bologna, Italy, 2007; pp. 1-467, ISBN 9788883723216. (In Italian)

68. Batzing, W. Le Alpi Italiane. Un'analisi dei Problemi Attuali nella Prospettiva di una Convenzione Alpina; Cipra Piccola Documentazione: Bolzano, Italy, 1990; p. 92, ISBN 3906521161. (In Italian)

69. UNCEM. L'Associazione Fondiaria per Rivitalizzare L'agricoltura in Montagna. Piemonti-Periodico D'informazione della Delegazione Piemontese UNCEM, Gennaio-Febbraio 2013. Available online: http:/ / www.comitato4p.org/docs/PieMonti_gennaio_febbraio_2013.pdf (accessed on 10 August 2017). (In Italian)

70. Anthelme, F.; Grossi, J.L.; Brun, J.; Didier, L. Consequences of green alder expansion on vegetation changes and arthropod communities removal in the northern French Alps. For. Ecol. Manag. 2001, 145, 57-65. [CrossRef] 
71. Laiolo, P.; Dondero, F.; Ciliento, E.; Rolando, A. Consequences of pastoral abandonment for the structure and diversity of the Alpine avifauna. J. Appl. Ecol. 2004, 41, 294-304. [CrossRef]

72. Cavallero, A.; Lombardi, G.P.; Tagliatori, C.; Martinasso, B.; Bruno, G.; Canavesio, A.; Ferrero, M.; Giaccone, D.; Perotti, P.; Puppo, C.; et al. Aspetti foraggero pastorali e Proposta di catasto pastorale delle Valli Ossolane. In Il Formaggio Ossolano; Quaderni Regione Piemonte Agricoltura, Regione Piemonte: Torino, Italy, 2002; Volume 31, pp. 51-184. (In Italian)

73. Lombardi, G.; Cavallero, A. Rispondenza e significato delle metodologie applicate alla realizzazione di catasti pastorali sulle Alpi occidentali. In Ricerca ed Innovazione per le Produzioni Vegetali e la Gestione delle Risorse Agro-Ambientali; Sia: Foggia, Italy, 2005; pp. 1-417, ISBN 9788874270101. (In Italian)

2018 by the authors. Licensee MDPI, Basel, Switzerland. This article is an open access article distributed under the terms and conditions of the Creative Commons Attribution (CC BY) license (http://creativecommons.org/licenses/by/4.0/). 